\title{
PEMODELAN PROSES BISNIS \\ ADMISI CALON MAHASISWA BARU DI UNIVERSITAS SAM RATULANGI
}

\author{
Stanley Karouw ${ }^{1)}$, Juan R Rarumangkay ${ }^{2)}$, Zwingly Rawis ${ }^{3)}$ \\ stanley.karouw@unsrat.ac.id; rarumangkajuanryan@gmail.com; chzrawis@gmail.com \\ Program Studi Teknik Informatika, Fakultas Teknik, Universitas Sam Ratulangi
}

\begin{abstract}
Abstrak
Penerimaan mahasiswa baru di Universitas Sam Ratulangi merupakan suatu proses bisnis yang diadakan secara rutin setiap tahun pada Masa Penerimaan Calon Mahasiswa Baru. Proses penerimaan mahasiswa baru di Universitas Sam Ratulangi ini dapat melalui 4 jalur, yaitu SNMPTN, SBMPTN, T2 dan Sumikolah. Pada paper ini, penulis menggunakan BPMN (Business Process Modelling Notation) untuk mendeskripsikan alur logis dari proses bisnis penerimaan mahasiswa baru yang dilakukan oleh Universitas Sam Ratulangi Manado. Paper ini menunjukkan bahwa BPMN dapat mendeskripsikan proses bisnis penerimaan mahassiwa baru. BPMN juga dapat mendeskripsikan proses bisnis tersebut dengan pendekatan grafis yang efisien dan mudah dipahami. BPMN dapat digunakan untuk menjelaskan kondisi nyata dari sebuah bisnis proses penerimaan mahassiwa baru yang dilakukan oleh Universitas Sam Ratulangi Manado.
\end{abstract}

Kata kunci: Proses Bisnis, Admisi, Universitas Sam Ratulangi, BPMN

\section{PENDAHULUAN}

Universitas Sam Ratulangi Manado (UNSRAT) merupakan salah satu dari beberapa Perguruan Tinggi Negeri (PTN) yang berlokasi di Sulawesi Utara. Setiap tahun Universitas Sam Ratulangi membuka beberapa jalur penerimaan mahasiswa baru, yaitu SNMPTN, SBMPTN, T2 dan Sumikolah. Seleksi Negeri Masuk Perguruan Tinggi Negeri (disingkat SNMPTN) atau disebut juga jalur undangan merupakan penerimaan mahasiswa baru pertama yang diadakan untuk masuk PTN yang diawali dengan seleksi 25\% siswa terbaik di sekolah yang sudah terakreditasi[2]. Jalur penerimaan berikutnya adalah Seleksi Bersama Masuk Perguruan Tinggi Negeri (atau SBMPTN). SBMPTN merupakan mekanisme seleksi masuk PTN melalui ujian tertulis dan keterampilan yang dilaksanakkan secara serentak di 62 PTN di seluruh Indonesia[3]. Jalur Tumou Tou (atau T2) merupakan penerimaan mahasiswa baru melalui ujian tertulis yang khusus berlaku di Universitas Sam Ratulangi Jalur penerimaan mahasiswa baru yang terakhir adalah Sumikolah. Program Sumikolah merupakan penerimaan mahasiswa baru terakhir yang ditujukkan untuk memenuhi kuota pada setiap jurusan atau program studi.

Hasil wawancara, kuesioner dan observasi yang dilakukan, menunjukkan adanya permasalahan yang terkait proses penerimaan mahasiswa baru tersebut diatas. Permasalahan yang terutama adalah terkait kurangnya pemahaman aktivitas proses bisnis penerimaan mahasiswa baru ini oleh calon mahasiswa baru dan panita penyelenggara kegiatan ini. Kurangnya informasi yang terkait dengan proses bisnis penerimaan mahasiswa baru menyebabkan pihak calon mahasiswa baru menghabiskan waktu yang lama untuk melakukan pendaftaran.

Paper ini memberikan solusi terkait permasalahan tersebut diatas, yakni bagaimana membuat model aktivitas proses bisnis penerimaan mahasiswa baru. Model proses bisnis dibangun dengan menggunakan kakas BPMN. Model proses bisnis penerimaan mahasiswa baru ini diharapkan dapat memberikan deskrpsi yang lengkap dan mendetail terkait aktivitas penerimaan mahasiswa baru di Universitas Sam Ratulangi Manado, sehingga diharapkan mengurangi waktu pendaftaran yang dilakukan calon mahasiswa baru.

\section{DASAR TEORI}

\subsection{Kerangka Penelitian}

Kerangka penelitian selengkapnya dapat dilihat pada Gambar 1. Kerangka penelitian terdiri dari tiga langkah utama:

1) Analisa Konteks dan Ruang Lingkup; dimana pada tahap ini dilakukan pengumpulan data. Data dikumpulkan dengan melakukan studi literatur, melakukan wawancara dan menyebarkan kuesioner. Studi literatur berupa dokumendokumen yang terkait perundang-undangan tentang Pendidikan Tinggi, dokumen tentang UNSRAT serta dokumen lainnya yang terkait. Wawancara dan kuesioner dilakukan pada pemangku kepentingan dalam lingkungan UNSRAT, seperti pimpinan manajemen utama, menengah dan pelaksana.

2) Identifikasi Proses Bisnis. Tahap kedua adalah melakukan kajian proses bisnis 
admisi (atau proses penerimaan calon mahasiswa baru). Proses bisnis disusun berdasarkan urutan peristiwa (atau aktivitas) beserta aktor yang terkait atau berperan pada peristiwa dan akativitas tersebut. Setelah itu, proses bisnis direkonstruksi kembali, dengan mempertimbangkan masukan dari pimpinan.

3) Pemodelan Proses Bisnis. Tahap ketiga ini merupakan langkah terakhir, yakni proses bisnis yang telah direkonstruksi ulang, dimodelkan dengan menggunakan kakas Business Process Notation Model versi 1.0 (BPMN).

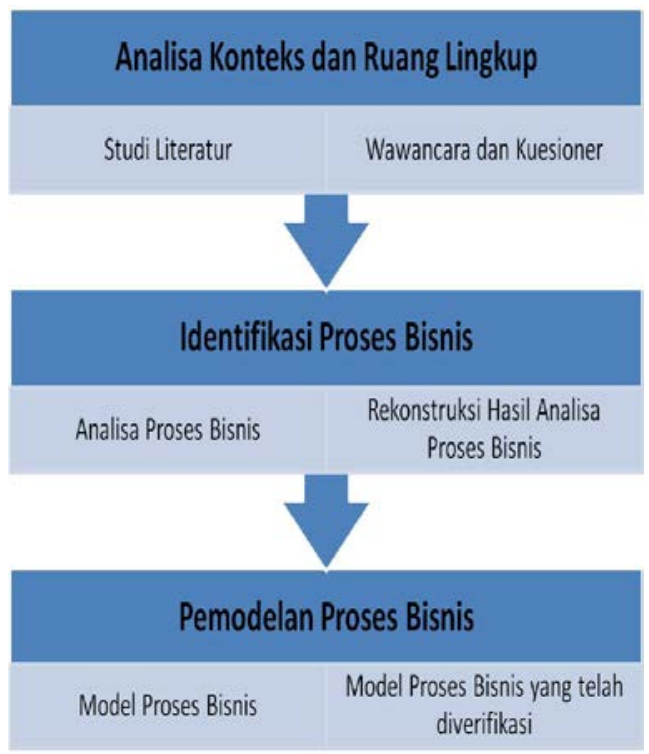

Gambar 1 Kerangka Penelitian

\subsection{BPMN}

Business Process Modeling Notation (disingkat BPMN) adalah representasi grafis untuk menentukan proses bisnis dalam suatu permodelan proses bisnis. Tujuan utama dari BPMN adalah menyediakan suatu notasi standar yang mudah dipahami oleh semua pemangku kepentingan bisnis sehingga dapat mempercepat pengambilan keputusan [3] BPMN merupakan metodologi baru yang dikembangkan oleh Process Modeling Initiative sebagai suatu standard baru pada permodelan proses bisnis. BPMN juga sebagai alat desain pada sistem yang kompleks berbasis pesan (message-based). Salah satu kelebihan diagram BPMN adalah kemampuan memodelkan aliran pesan. Diagram bisnis proses tradisional mampu memodelkan aliran proses secara sekuensial, dari kejadian awal sampai hasil akhir [4]. Contoh penerapan notasi pada sistem berbasis layanan web adalah seperti Gambar 1.

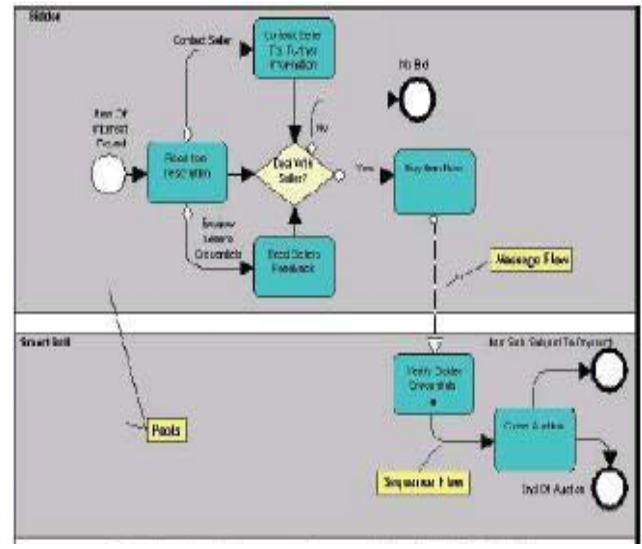

Gambar 2 Contoh Diagram BPMN

\section{PEMBAHASAN}

Proses bisnis yang dikembangkan merupakan proses admisi (atau penerimaan) calon mahasiswa baru, yang berlaku di UNSRAT.

\subsection{Jalur Masuk SNMPTN}

Untuk mengikuti SNMPTN, harus melalui 2 tahap yaitu pengisian PDSS dan pendaftaran. PDSS (Pangkalan Data Sekolah dan Siswa) merupakan sistem dimana sekolah memasukkan nilai rapor siswa untuk proses seleksi SNMPTN.

Langkah aktivitas berurut dari jalur masuk SNMPTN, adalah sebagai berikut:

PDSS:

1. Kepala Sekolah mengisi data sekolah dan calon mahasiswa baru di PDSS melalui laman http://pdss.snmptn.ac.id.

2. Kepala Sekolah mendapatkan password setiap calon mahasiswa baru yang akan digunakan untuk melakukan verifikasi.

3. Calon mahasiswa baru melakukan verikasi data rekam jejak prestasi akademik yang diisikan oleh Kepala Sekolah dengan menggunakan NISN dan password yang diberikan oleh Kepala Sekolah.

4. Bagi calon mahasiswa baru yang tidak melaksanakan verifikasi maka data rekam jejak prestasi akademik yang diisikan oleh Kepala Sekolah dianggap benar dan tidak dapat diubah setelah waktu verifikasi berakhir.

Pendaftaran:

5. Calon mahasiswa baru, menggunakan NISN dan password, yang diberikan oleh Kepala Sekolah pada waktu verifikasi data di PDSS, login ke laman SNMPTN http:// snmptn.ac.id untuk melakukan pendaftaran.

6. Calon mahasiswa baru mengisi biodata, pilihan PTN, dan pilihan program studi, serta mengunggah (upload) pasfoto resmi terbaru dan dokumen prestasi tambahan. Calon mahasiswa baru harus membaca 
dan memahami seluruh ketentuan yang berlaku pada PTN yang akan dipilih.

7. Kepala Sekolah harus memberi rekomendasi kepada calon mahasiswa baru yang sudah mendaftar SNMPTN.

8. Calon mahasiswa baru program studi keolahragaan dan seni harus mengunggah portofolio atau dokumen bukti keterampilan yang diisi oleh Kepala Sekolah.

9. Calon mahasiswa baru mencetak kartu bukti pendaftaran sebagai tanda bukti peserta SNMPTN.

10. Calon mahasiswa baru menunggu pengumuman hasil seleksi yang bisa dilihat di http:// snmptn.ac.id/hasil-seleksi sesuai tanggal yang ditentukan.

11. Jika lulus seleksi pada jurusan atau program studi di Universitas Sam Ratulangi, maka calon mahasiswa baru memasukkan berkas di Auditorium dengan syarat-syarat seperti gambar 6 .

12. Melakukan negosiasi SPP di audiotriom dengan petugas sesuai dengan fakultas, dimana calon mahasiswa baru diterima.

13. Calon mahasiswa baru melakukan pembayaran SPP melalui sistem pembayaran SPC dengan menyebutkan nomor pendaftaran di BTN (Bank Tabungan Negara).

14. Melakukan registrasi kembali dengan membawa bukti slip pembayaran SPP, dimana mahasiswa diterima.

15. Calon mahasiswa baru mengambil NIM dan memasukkan pas foto (soft copy) di kantor pusat.

16. Calon mahasiswa baru mendapatkan smartcard sesuai tanggal yang ditentukan dan bertempat di kantor pusat.

17. Calon mahasiswa baru terdaftar di Universitas Sam Ratulangi

Setelah dilakukan rekonstruksi proses bisnis, maka tahapan aktivitas proses bisnis jalur masuk SMNPTN menjadi seperti sebagai berikut:

PDDS

1. Kepala Sekolah mengisi data sekolah dan calon mahasiswa baru di PDSS melalui laman http://pdss.snmptn.ac.id

2. Kepala Sekolah mendapatkan password setiap calon mahasiswa baru yang akan digunakan untuk melakukan verifikasi.

3. Calon mahasiswa baru melakukan verikasi data rekam jejak prestasi akademik yang diisikan oleh Kepala Sekolah dengan menggunakan NISN dan password yang diberikan oleh Kepala Sekolah.

4. Bagi calon mahasiswa baru yang tidak melaksanakan verifikasi maka data rekam jejak prestasi akademik yang diisikan oleh Kepala Sekolah dianggap benar dan tidak dapat diubah setelah waktu verifikasi berakhir.

Pendaftaran

5. Calon mahasiswa baru, menggunakan NISN dan password, yang diberikan oleh Kepala Sekolah pada waktu verifikasi data di PDSS, login ke laman SNMPTN http:// snmptn.ac.id untuk melakukan pendaftaran.

6. Calon mahasiswa baru mengisi biodata, pilihan PTN, dan pilihan program studi, serta mengunggah (upload) pasfoto resmi terbaru

dan dokumen prestasi tambahan. Calon mahasiswa baru harus membaca dan memahami seluruh ketentuan yang berlaku pada PTN yang akan dipilih.

7. Kepala Sekolah harus memberi rekomendasi kepada calon mahasiswa baru yang sudah mendaftar SNMPTN.

8. Calon mahasiswa baru program studi keolahragaan dan seni harus mengunggah portofolio atau dokumen bukti keterampilan yang diisi oleh Kepala Sekolah.

9. Calon mahasiswa baru mencetak kartu bukti pendaftaran sebagai tanda bukti peserta SNMPTN.

10. Calon mahasiswa baru menunggu pengumuman hasil seleksi yang bisa dilihat di http:// snmptn.ac.id/hasil-seleksi sesuai tanggal yang ditentukan.

11. Jika lulus seleksi pada jurusan atau program studi di Universitas Sam Ratulangi, maka calon mahasiswa baru memasukkan berkas di Auditorium dengan syarat-syarat seperti gambar 6 .

12. Negosiasi dihilangkan dan digani dengan penyelarasan sesuai data/berkas oleh sebuah aplikasi yang dimana SPP disesuaikan dengan pekerjaan dan pendapatan orangtua atau calon mahasiswa.

13. Calon mahasiswa baru melakukan pembayaran SPP melalui sistem pembayaran SPC dengan menyebutkan nomor pendaftaran di semua Bank mana saja.

14. Melakukan registrasi kembali dengan membawa bukti slip pembayaran SPP disertakan dengan pemasukkan pas foto (soft copy) sehingga ada perangkat lunak yang dapat membuat mahasiswa bisa langsung mendapatkan NIM dan Smartcard, dimana mahasiswa diterima.

Jadi, terdapat beberapa perbaikan dari proses bisnis yang pertama, dengan proses bisnis yang telah direkonstruksi ulang. Model proses bisnis SNMPTN yang telah direkonstruksi ulang, dapat dilihat pada Gambar 3. 


\subsection{Jalur Masuk SBMPTN}

Untuk mengikuti SBMPTN, Universitas Sam Ratulangi menyediakan tempat untuk melakukan tes kepada setiap orang yang ingin melanjutkan ke salah satu dari 62 PTN di Indonesia. Pada setiap calon mahasiswa baru yang akan mengikuti SBMPTN, diwajibkan mengikuti proses-proses dibawah ini:

1. Calon mahasiswa baru melakukan pembayaran ke Bank Mandiri dan membawa kartu keluarga/KTP/SKHUN dengan perincian biaya sebagai berikut:
a. IPA (saintek) = Rp.175.000
b. IPS (soshum) $=$ Rp. 175.000
c. IPC $($ campuran $)=$ Rp. 200.000

2. Mendapatkan PIN dan password yang diberikan pihak Bank.

3. Melakukan pengisisan data secara online di http:// ujian.sbmptn.or.id

4. Mencetak kartu ujian, sebagai tanda bukti peserta SBMPTN.

5. Mengikuti ujian tertulis sesuai dengan ruangan yang tertera pada kartu ujian dan membawa kartu ujian yang sudah dicetak juga membawa SKHUN yang telah dilegalisasir.

6. Menunggu hasil pengumuman seleksi yang bisa dilihat di http:// pengumuman.sbmptn.or.id/umum.php sesuai tanggal yang ditentukan.

7. Jika lulus seleksi, maka calon mahasiswa baru memasukkan berkas dengan syaratsyarat seperti gambar 6 dan membawa ke auditorium Universitas Sam Ratulangi.

8. Melakukan negosiasi SPP di audiotriom dengan petugas sesuai dengan fakultas, dimana calon mahasiswa baru diterima.

9. Calon mahasiswa baru melakukan pembayaran SPP melalui sistem pembayaran SPC dengan menyebutkan nomor pendaftaran di BTN (Bank Tabungan Negara).

10. Melakukan registrasi kembali dengan membawa bukti slip pembayaran SPP, dimana mahasiswa diterima.

11. Calon mahasiswa baru mengambil NIM dan memasukkan pas foto (soft copy) di kantor pusat.

12. Calon mahasiswa baru mendapatkan smartcard sesuai tanggal yang ditentukan dan bertempat di kantor pusat.

13. Calon mahasiswa baru terdaftar di Universitas Sam Ratulangi.

\subsection{Jalur Masuk Tumou Tou (T2)}

Proses-proses yang wajib diikuti oleh calon mahasiswa baru yang akan mengikuti jalur T2, yaitu:

1. Calon mahasiswa melakukan pembayaran di BRI (Bank Raktat Indonesia) dan membawa kartu keluarga/KTP/SKHUN dengan perincian biaya sebagai berikut:
a. $\quad$ IPA (saintek) $=$ Rp.27.500
b. IPS (soshum) $=$ Rp. 27.500
c. $\quad$ IPC $($ campuran $)=$ Rp.32.500

2. Mendapatkan PIN dan password yang diberikan pihak Bank.

3. Melakukan pengisian data secara online di http:// um.unsrat.ac.id

4. Mencetak kartu ujian, sebagai tanda bukti peserta T2.

5. Mengikuti ujian tertulis dengan membawa kartu ujian yang sudah dicetak dan membawa SKHUN yang telah dilegalisasir.

6. Menunggu hasil pengumuman seleksi yang bisa dilihat di http://um.unsrat.ac.id sesuai tanggal yang ditentukan.

7. Jika lulus seleksi, maka calon mahasiswa baru memasukkan berkas dengan syaratsyarat seperti gambar 6 dan membawa ke auditorium Universitas Sam Ratulangi.

8. Melakukan negosiasi SPP di audiotriom dengan petugas sesuai dengan fakultas, dimana calon mahasiswa baru diterima.

9. Calon mahasiswa baru melakukan pembayaran SPP melalui sistem pembayaran SPC dengan menyebutkan nomor pendaftaran di BTN (Bank Tabungan Negara).

10. Melakukan registrasi kembali dengan membawa bukti slip pembayaran SPP, dimana mahasiswa diterima.

11. Calon mahasiswa baru mengambil NIM dan memasukkan pas foto (soft copy) di kantor pusat.

12. Calon mahasiswa baru mendapatkan smartcard sesuai tanggal yang ditentukan dan bertempat di kantor pusat.

13. Calon mahasiswa baru terdaftar di Universitas

Sam Ratulangi.

\subsection{Rekonstruksi Proses Bisnis Jalur Masuk SBMPTN, T2 dan Sumikolah}

Pada bagian ini dipaparkan mengenai rekonstruksi proses bisnis jalur masuk SBMPTN, T2 dan Sumikolah. Proses aktivitas ketiga proses bisnis ini dapat direkonstruksi ulang, dengan menggabungkan langkah proses aktivitas yang terkait. Langkah proses aktivitasnya adalah sebagi berikut:

1. UNSRAT dapat memfasilitasi calon mahasiswa baru agar bisa melakukan pembayaran di Bank mana saja.

2. Calon mahasiswa baru melakukan pembayaran ke Bank dan membawa kartu keluarga/KTP/SKHUN dengan perincian biaya sebagai berikut:

a. SBMPTN:

1) IPA (saintek) $=$ Rp. 175.000 
2) IPS (soshum) $=$ Rp.175.000

3) IPC (campuran) = Rp. 200.000

b. T2 dan Sumikolah:

1) IPA (saintek) $=$ Rp.27.500

2) IPS (soshum) $=$ Rp.27.500

3) IPC (campuran) $=$ Rp.32.500

3. Mendapatkan PIN dan password yang diberikan pihak Bank.

4. Melakukan pengisisan data secara online pada:

a. SBMPTN: http:// ujian.sbmptn.or.id

b. T2 dan Sumikolah: $\underline{\text { http:// }}$ um.unsrat.ac.id

5. Mencetak kartu ujian, sebagai tanda bukti peserta SBMPTN/T2/Sumikolah.

6. Mengikuti ujian tertulis sesuai dengan ruangan yang tertera pada kartu ujian dan membawa kartu ujian yang sudah dicetak juga membawa SKHUN yang telah dilegalisasir.

7. Menunggu hasil pengumuman seleksi yang bisa dilihat pada:
a. SBMPTN
http://
pengumuman.sbmptn.or.id/umum .php
b. $\frac{. p 2}{\mathrm{~T} 2}$ dan Sumikolah: http://

8. Jika lulus seleksi, maka calon mahasiswa baru memasukkan berkas dengan syaratsyarat seperti gambar 6 dan membawa ke auditorium Universitas Sam Ratulangi.

9. Melakukan negosiasi SPP di audiotriom dengan petugas sesuai dengan fakultas, dimana calon mahasiswa baru diterima.

10. Calon mahasiswa baru melakukan pembayaran SPP melalui sistem pembayaran SPC dengan menyebutkan nomor pendaftaran di Bank mana saja.

11. Melakukan registrasi kembali dengan membawa bukti slip pembayaran SPP disertakan dengan pemasukkan pas foto (soft copy) sehingga ada perangkat lunak yang dapat membuat mahasiswa bisa langsung mendapatkan NIM dan Smartcard, dimana mahasiswa diterima.

12. Calon mahasiswa baru terdaftar di Universitas Sam Ratulangi.

Model rekonstruksi proses bisnis penerimaan calon mahasiswa baru dengan jalur masuk SBMPTN, T2 dan Sumikolah selengkapnya dapat dilihat pada Gambar 4.

\section{Kesimpulan}

Beberapa kesimpulan yang bisa diambil adalah sebagai berikut:

1. Pemodelan proses bisnis dengan menggunakan BPMN dapat menjelaskan dengan efisien proses bisnis penerimaan mahasiswa baru yang dilakukan di Universitas Sam Ratulangi dengan pendekatan grafis.

2. BPMN dapat mendeskripsikan model proses bisnis penerimaan mahasiswa baru pada jalur SMNPTN, SBMPTN, T2 dan Sumikolah. Pemodelan ini merupakan penjelasan dari urutan aktivitas nyata yang terjadi.

3. Model BPMN dapat digunakan untuk merancang proses bisnis usulan dari kegiatan penerimaan mahasiswa baru yang dilakukan oleh Universitas Sam Ratulangi Manado.

\section{Daftar Pustaka}

[1] Suryatiningsih (2013) ,Pemodelan proses bisnis B2C dengan BPMN(studi kasus Konfreksi pada Basar Clothing. Proceedings Konferensi Nasional Sistem Informasi (KNSI) 2013.

[2] Website Resmi SBMPTN www.sbmptn.web.id/2011/10/pengertiansbmptn-jalur-undangan.html, diakses pada Selasa, 30 April 2013, 12.00 PM.

[3] Object Management Group, 2011., Business Process Modelling and Notation BPMN, Needhan: OMG

[4] Rosmala, Dewi dan Falahah, 2007., Pemodelan Proses Bisnis B2C dengan BPMN, Indonesia. 


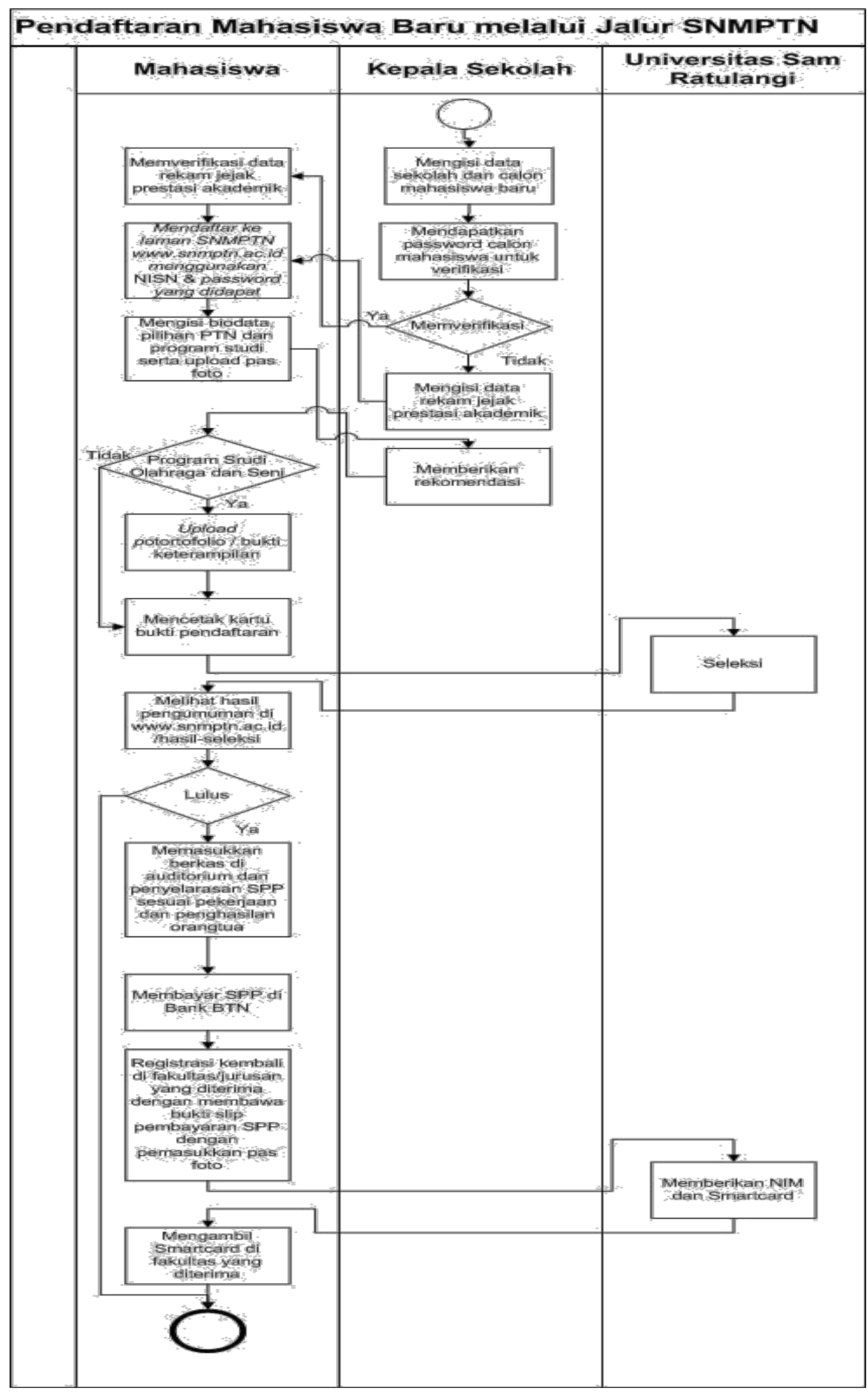

Gambar 3 Proses Bisnis Admisi Calon Mahasiswa Baru di UNSRAT dengan jalur SNMPTN 


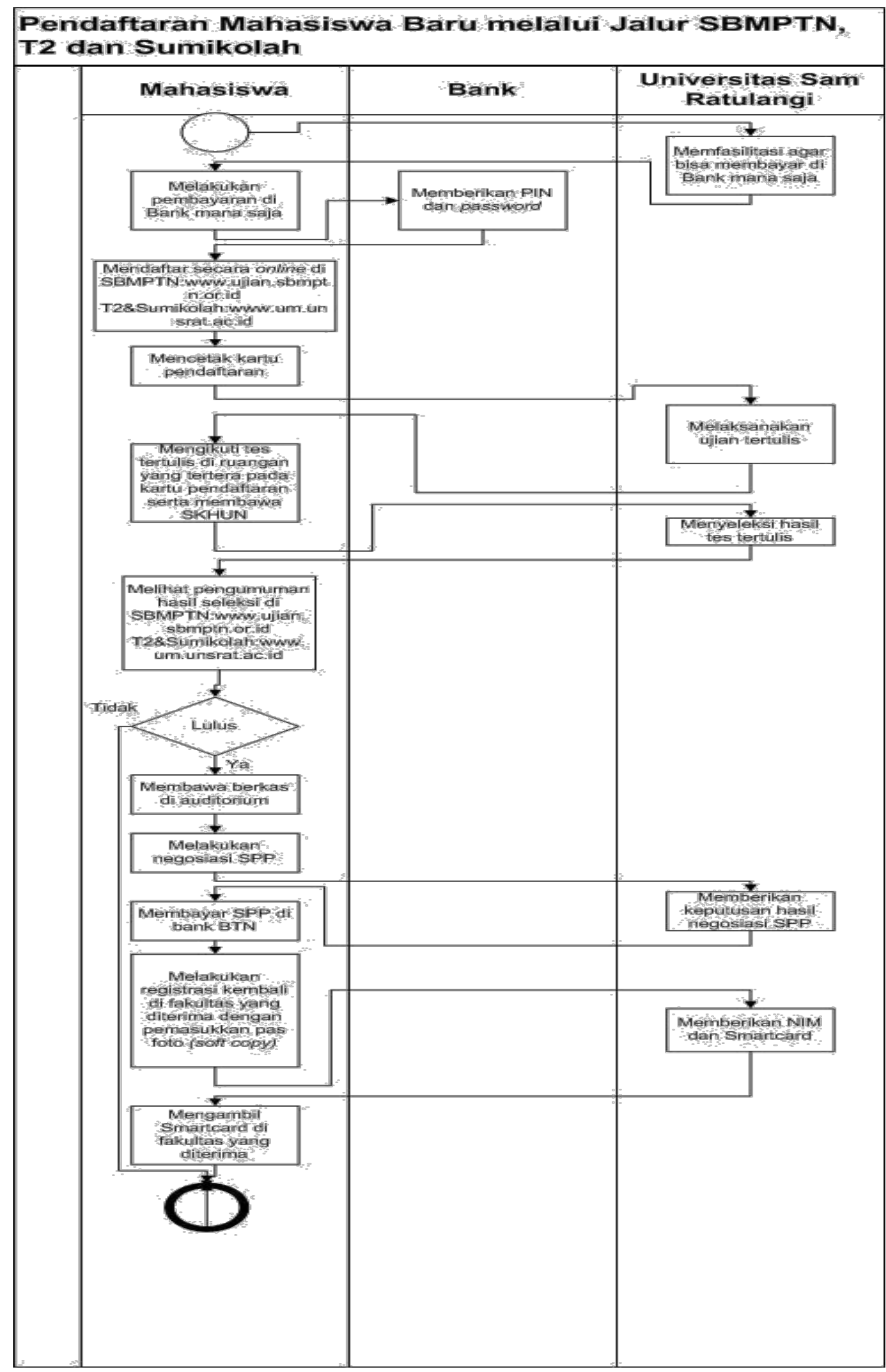

Gambar 4 Proses Bisnis Penerimaan Mahasiswa Baru di Universitas Sam Ratulangi Jalur SBMPTN, T2 dan Sumikolah 